\title{
Leiomyoma of vulva mimmicking bartholin cyst
}

\author{
Anju Singh*, Bharti Goel, Navneet Takkar, Ekta Jain
}

Department of Obstetrics and Gynaecology, Government Medical College and Hospital, Chandigarh, Punjab, India

Received: 22 October 2016

Revised: 24 October 2016

Accepted: 17 November 2016

\section{*Correspondence:}

Dr. Anju Singh,

E-mail: singha1712@gmail.com

Copyright: ( $)$ the author(s), publisher and licensee Medip Academy. This is an open-access article distributed under the terms of the Creative Commons Attribution Non-Commercial License, which permits unrestricted non-commercial use, distribution, and reproduction in any medium, provided the original work is properly cited.

\begin{abstract}
Leiomyoma of vulva are uncommon findings in women of reproductive age group. It is often misdiagnosed as Bartholin cyst as unilateral swelling of vulva in women of reproductive age group is commonly a bartholin cyst or abscess. We describe a case of leiomyoma that clinically mimicked bartholin duct cyst. Identification of leiomyoma or leiomyosarcoma is necessary because of risk of recurrence, need of radiation and or chemotherapy in addition to surgical excision whereas standard treatment for bartholin cyst is marsuplisation.
\end{abstract}

Keywords: Bartholin cyst, Leiomyoma, Vulva

\section{INTRODUCTION}

Unilateral swelling of vulva in a woman of reproductive age group is commonly a bartholin cyst or abscess. ${ }^{1}$ Leiomyoma of vulva is very rare presentation. The origin of this smooth muscle tumor are from smooth muscle within erectile muscle, the round ligament, blood vessels walls, the dartos muscle or arrector pili muscle. ${ }^{2}$ Here we present a case of leiomyoma of vulva misterpreted as bartholin cyst being unaware it can be leiomyoma of vulva due to its rare presentation.

\section{CASE REPORT}

A 45 year old multiparous lady presented with swelling in vulva for last four months leading to dyspareunia and swelling in genital region. Gradually mass had increased from pea size to $5 \times 4 \mathrm{~cm}$. There was no history of fever, vaginal discharge or trauma. Her general condition was fair and vitals were stable. Local examination revealed swelling of $5 \mathrm{X} 4 \mathrm{~cm}$ in posterior half of left labia majora and was non tender.

There was no erythema of overlying skin or warmth on touch .Diagnosis of bartholin cyst was made and decision for marsuplisation taken after investigations. She was diagnosed to have diabetes and her blood sugar was controlled by insulin prior to surgery.

An incision was given was given on inner side of labium minus just outside hymenal tag. After separating overlying skin a firm cystic mass felt. It was thick walled and multiloculated with minimal blood clots in one of the loculi. Base of cyst was thick and going deep behind inferior pubic ramus so clamps applied as distally as possible and pedicle cut and ligated. Cyst sent for histopathological examination. Cavity obliterated by delayed absorbable sutures. Histopathological report revealed tumor composed of fascicles and interlacing bundles of spindle shaped tumor cells having bland nuclear features intervening areas show foci of haemorrhage, oedema, hyalinization, myxoid changes and cystic changes (Figure 1, 2). Thick walled blood vessels seen. No necrosis seen. Tissue cells were positive for smooth muscle actin (SMA).Thus final diagnosis leiomyoma with secondary changes was ascertained.

Postoperative period was uneventful. Patient is on regular follow up and there is no recurrence of fibroid. 


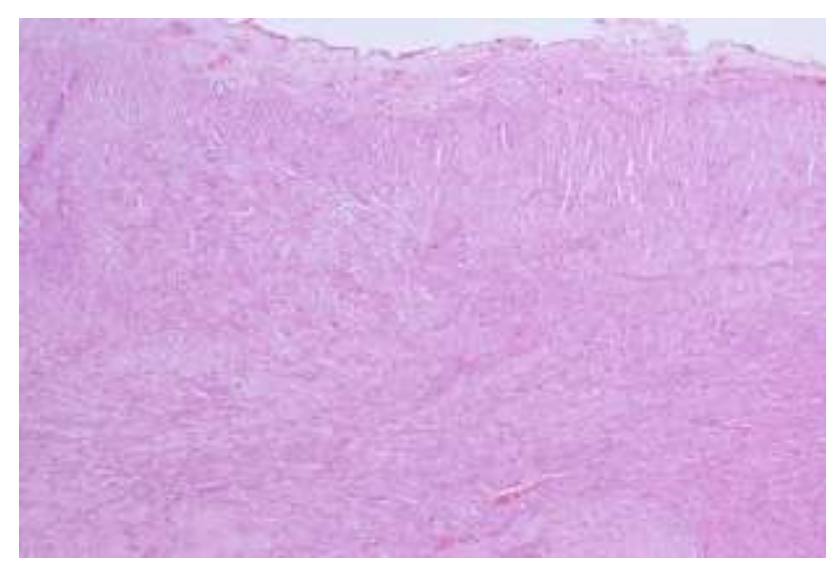

Figure 1: Tumor in subepithelium composed of fascicles and interlacing bundles of tumor cells $(\mathrm{H}$ and E X40).

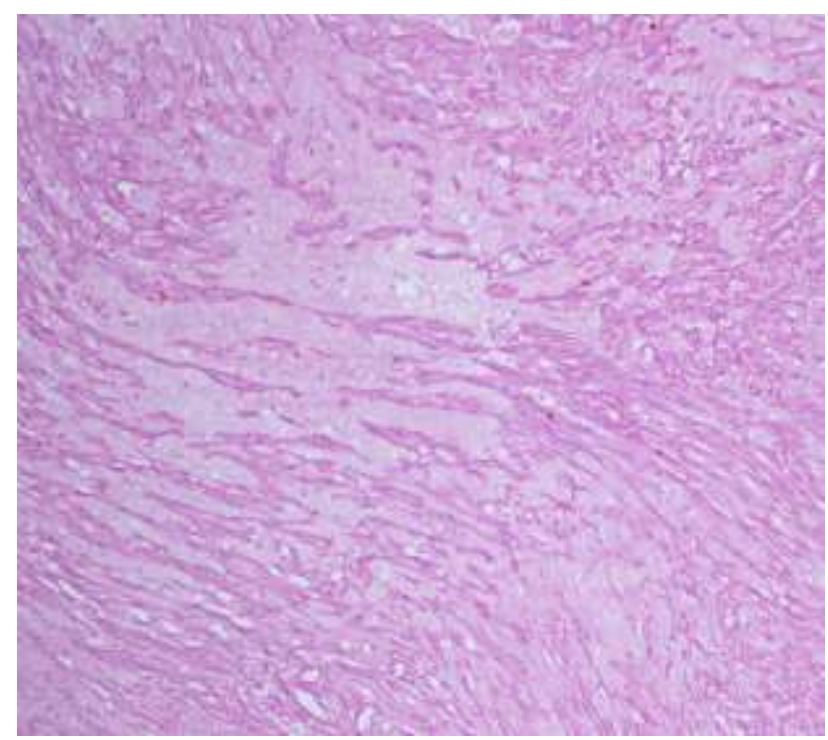

Figure 2: Tumor cells are spindle shape with bland nuclear features. Intervening areas show hyaline changes ( $H$ and $\mathbf{E} X \mathbf{4 0})$.

\section{DISCUSSION}

Leiomyoma is very commonly seen in the uterus but rarely in vulva, ovaries, urethra and urinary bladder. After reviewing 144 cases of leiomyoma only one case was found to be leiomyoma by Reidel et al. ${ }^{3}$ Leiomyoma can arise in any anatomical site. ${ }^{4,5}$ Leiomyoma of vulva accounts for $0.03 \%$ of all patients with gynaecological neoplasm. These tumor are considered to originate from smooth muscle within erectile tissue, blood vessels walls, the round ligament, the dartos muscle or arrector pilli muscle and from stem cells localized in bartholin gland. It usually present as spindle shaped cells but other histological types such as epitheloid tumors are also reported.

Clinicopathological features of 25 cases of leiomyoma of vulva were reviewed by Neilsen et al. ${ }^{6}$ Most of them were diagnosed initially as bartholin cyst. Clinical symptoms include painless mass, pain, itching and erythema. Pathologically 20 of them were leiomyoma and 5 were leiomyosarcoma. Similar cases are reported by Levy et al. $^{7}$

Coexistence of leiomyoma of vulva and esophagus was first reported in mother and her daughter from Helsingborg, Sweden. ${ }^{8}$

Leiomyoma of vulva presents with features similar to those of bartholin cyst. It is a diagnostic dilemma. ${ }^{1}$ In our case too features suggested of bartholin cyst and it was misinterpreted as bartholin cyst.

The diagnosis of vulval leiomyoma can be established by transperineal ultrasonography. Benign and malignant form can be differentiated with the help of magnetic resonance imaging. ${ }^{4}$ A characteristic finding of low signal intensity mimicking that of smooth muscle on T2 weighted images is the key to diagnosis. The MR signal in the tumor is isointense to that in muscle on $\mathrm{T} 1$ weighted images and tumor enhance homogenously after the administration of contrast material.

Surgical excision is the treatment of choice in all smooth muscle tumors of vulva. Histopathological confirmation is must to rule out any malignancy. Long term follow up is mandatory.

Bartholin duct cyst near the orifice is common. Obstruction of the duct can result from gonococcal infection; other infections and trauma more commonly explain the occlusion. During mediolateral episiotomy and postetior colporrhaphy suture can easily injure or even ligate the duct. Asymptomatic bartholin cysts do not need any treatment. Symptomatic cyst requires marsuplisation as treatment of choice. As chances of malignancy is higher in older patient excision of the cyst needed. Our patient was of 45 years of age, base of cyst indurated and going deep. Decision for excision of cyst was taken so as not to miss any malignancy.

The other differential diagnoses of vulval swelling other than bartholin cyst are fibroma, lymphangiomas, soft tissue sarcoma and neurogenic tumors.

So when there is vulval swelling which is firm in consistency leiomyoma should be kept as one of the differential diagnosis and biopsy must be done so as not to miss any leiomyosarcoma.

\section{CONCLUSION}

Leiomyoma of uterus is very common but of vulva is very rare condition. It is usually misinterpreted as bartholin cyst. So when a lady in late reproductive age group presents with unilateral swelling in vulvar region with firm consistency leiomyoma should be kept as 
differential diagnosis. Excision of mass should be the treatment so as not to miss any malignancy.

Funding: No funding sources

Conflict of interest: None declared

Ethical approval: Not required

\section{REFERENCES}

1. Pandey D, Shetty J, Saxena A, Shrilata P. Leiomyoma of vulva: A Diagnostic Dilemma. Case reports in Obstetrics and Gynecology. 2014 Article ID 386432

2. Kaufman RH, Gardner HL. A rare case of Primary leiomyoma of the vulva. J Obstet Gynaec. 1965;8(4):953-81.

3. Riedel V. Zysten und Geschwulste des ausseren Genitale und der Vagina. Zentralblatt für Gynäkologie. 1964;86:1597-08.

4. Fasih N, Shanbhogue AKP. Leiomyomas beyond the uterus: unusual locations, rare manifestations. Radiographics. 2008;28(7):1931-8.
5. Rani S, Sehgal A, Bhalla V, Takkar N. Leiomyoma demanding multidisciplinary approach: Case report. SEAJCRR. 2013;2(2):136-8.

6. Nielsen GP, Rosenberg AE. Scully. Smooth-muscle tumors of the vulva: a clinicopathological study of 25 cases and review of the literature. The American Journal of Surgical Pathology.1996;20(7):779-93.

7. Levy R, Winham W, Bryant C. Smooth muscles neoplasm of the vulva masquerading as Bartholin gland duct cyst. Obstet Gynecol. 2014;27(1):25-7.

8. Wahlén T, Åstedt B. Familial occurrence of coexisting Leiomyoma of vulva and esophagus. Acta ObstEtricia et Gynecologica Scandinavica. 1965;44(1):197-203.

Cite this article as: Singh A, Goel B, Takkar N, Jain E. Leiomyoma of vulva mimmicking bartholin cyst. Int J Reprod Contracept Obstet Gynecol 2017;6:3068 . 